\title{
IDENTIFICATION OF KAMPUNG NAGA CULTURAL POTENTIAL IN SUPPORTING THE REALIZATION OF GEOPARK GALUNGGUNG
}

\author{
Cahya Darmawan ${ }^{1, *}$, Siti Fadjarajani ${ }^{1}$, Iman Hilman $^{1}$ \\ ${ }^{1}$ Geography Education Departement, Postgraduate Program, Siliwangi University \\ *Email: 198103015@student.unsil.ac.id
}

\begin{abstract}
Geopark Galunggung is a platform that accommodates geodiversity, biodiversity and cultural diversity in Tasikmalaya Regency. Kampung Naga is part of the Geopark Galunggung development area.The method used in this study is a qualitative descriptive method. Data collection techniques by observation, interviews, documentation studies and literature studies. The purpose of this study is to identify and inventory the cultural potential that exists in the Geopark Galunggung area so as to produce a dossier manuscript of the Geopark Galunggung. The results of the study classify cultural potential into two, namely tangible potential including (1) Cultural heritage objects including Sanusantara heirlooms; (2) Cultural heritage buildings include Kampung Naga Traditional House, Bumi Ageung, Bale Patemon, Assalam Mosque, Kujang Heritage Monument, Saung lisung, rice barn; (3) There is no cultural heritage structure at the research site; (4) Cultural heritage sites include the Pangsolatan site and the Lumbung site; (5) The cultural conservation area covers the entire area kampung Naga. As well as intangible potential consisting of (1) Traditions and Oral Expressions; (2) Performing arts such as terebang gembrung, terebang sajak, angklung buhun; (3) Customs include traditional ceremonies, marak, hajat karya; (4) Community knowledge includes community farming systems, availability of homestays, Tour Guides Association, Community UMKM; (5) Proficiency in traditional woven bamboo crafts. These tangible and intangible potentials still exist today because they are preserved and passed on to the next generation.
\end{abstract}

Keywords: Geopark Galunggung; Kampung Naga; Cultural Potential.

\section{A. INTRODUCTION}

Tasikmalaya Regency is administratively part of West Java Province with an area of 270,882 $\mathrm{Ha}$, has 39 sub-districts and 351 villages. The wealth owned by Tasikmalaya Regency includes diverse geological, biological and cultural riches that encourage the West Java Provincial government to make Tasikmalaya Regency a Geopark development area (Gubernur Jawa Barat 2018). Geopark Galunggung is a designation for Geoparks in Tasikmalaya Regency, to accelerate the realization of Geoparks, an acceleration team is formed and then determines the delineation of the development area for the Geopark
Galunggung. Salawu District has a Cultural Potential that is already known by everyone, namely Kampung Naga.

Public knowledge about geoparks is still very limited, even though good geopark management can certainly have a huge influence on the economic development of the community. Geopark is an area that contains a wealth of geological, biological and cultural heritage that is developed in a sustainable manner for local community empowerment, scientific and cultural development and as a conservation area (Fahrudi and Wiratmoko 2018). The existence of a Geopark can be used as a 
natural laboratory and tourism destination, which in its realization requires support from across sectors as well as from various multidisciplinary sciences (Darmawan, Fadjarajani, and Hilman 2021).

The potential possessed by an area must be utilized, processed and used as well as possible. The existence of a geopark is expected to be a strategy for sustainable regional development while still taking into account aspects of geological, biological and cultural wealth management (Stoffelen et al. 2019). For this reason, the development of a geopark area other than as a conservation and education area is also an effort to promote a tourism area. The implementation of tourism in traditional areas while still paying attention to the cultural values of the local community will have its own charm in the development of tourism areas (Goeldner, R., and Ritchie 2012). Where the ultimate goal of the existence of this geopark is to improve people's lives for the better in various sectors (Nurhanifa, Konety, and Affandi 2020).

In the realization of a Geopark, there are three pillars that must be met so that the area is called a geopark area, namely aspects of geodiversity, biodiversity and cultural diversity (Kusumahbrata 2020). The aspect of cultural diversity is an aspect that is closely related to people's lives and can be formed because of a past cultural inheritance. The cultural diversity found in an area is a form of heritage that must be appreciated, maintained and preserved (Taylor 2013). Culture can function as a foundation that needs to be considered in managing its resources to realize equitable development without creating an imbalance (Faisal, Rindarjono, and Muryani 2016).
According Kamardi (2007) cultural diversity is a form of past and present culture that is both tangible and intangible. The tangible form of culture is tangible, tangible and can be touched. Meanwhile, intangible culture is concrete and cannot be held (Timang, Antariksa, and Ari 2016).

Kampung Naga is a traditional community that still adheres to the customs and culture of its ancestors to this day. The people of Kampung Naga live in a simple way and in harmony with nature and have a traditional community life style (Illiyani 2018). Until now, the people of Kampung Naga are very respectful and carry out the traditions of their ancestors so that it becomes a habit. The cultural potential in Kampung Naga is very diverse, so Kampung Naga is very suitable to be used as a reference for learning about culture, elements of this culture can be seen from the lifestyle and habits of the people of Kampung Naga. In this regard, the author will describe the cultural potential that exists in Kampung Naga, both tangible and intangible and besides that as a form of promoting the Galunggung Geopark in Tasikmalaya Regency.

\section{B. MATERIALS AND METHODS}

The method used in this study is a descriptive method with a qualitative approach. Qualitative descriptive research is suitable for use in this study because it is in accordance with the characteristics of the study, namely describing and explaining a phenomenon (Sukmadinata 2015).

The focus of this research is to identify the tangible and intangible cultural potential in Kampung Naga. The object of this research is the cultural 
potential in Kampung Naga, while the subjects are the elders of Kampung Naga, members of the Kampung Naga Tour Guide Association (HIPANA) and the indigenous people of Kampung Naga. The research location was carried out in Naga Village, Naga Hamlet, Neglasari Village, Salawu District. Data collection techniques by means of observation, interviews, documentation studies and literature studies.

Data analysis and processing techniques include the collection stage, the data reduction stage, the data presentation and the conclusion drawing stage. Then the data is processed and analyzed by descriptive analysis techniques and data triangulation. Descriptive analysis technique is used to process and analyze research problems. Meanwhile, the triangulation technique was used to validate the answers obtained from the informants regarding the research problem being asked (Bachri 2010).

\section{RESULTS AND DISCUSSION}

The existence of the Geopark Galunggung is still new so it requires support and contributions from all parties. The Geopark Galunggung Acceleration Team must of course be able to take inventory and identify all the potentials in the Geopark Galunggung area, both based on aspects of geodiverity, biodiversity and cultural diversity. One area that supports the existence of the Geopark Galunggung in the cultural aspect is the Kampung Naga area.

Kampung Naga is a traditional village that still adheres to the customs and traditions of its ancestors. Kampung Naga is located in Neglasari Village, Salawu District. The population in Kampung Naga is \pm 300 residents with 102 family heads (Pemerintah Desa Neglasari 2020). The area of Kampung Naga which is used as a settlement is \pm 1.5 hectares. While the area of Kampung Naga is not limited by administrative boundaries, as far as the place where the indigenous naga live, it is still said to be the Kampung Naga area. Currently, the descendants of the Kampung Naga are widely spread in two sub-districts, namely Salawu District and Cigalontang District. For the Naga community who already resides outside, they are called community members and the term for the Kampung Naga community is called Naga citizen. There is no difference between the rights and obligations of the naga residents and the community members, so when there is a traditional ceremony, all the naga communities are involved. 


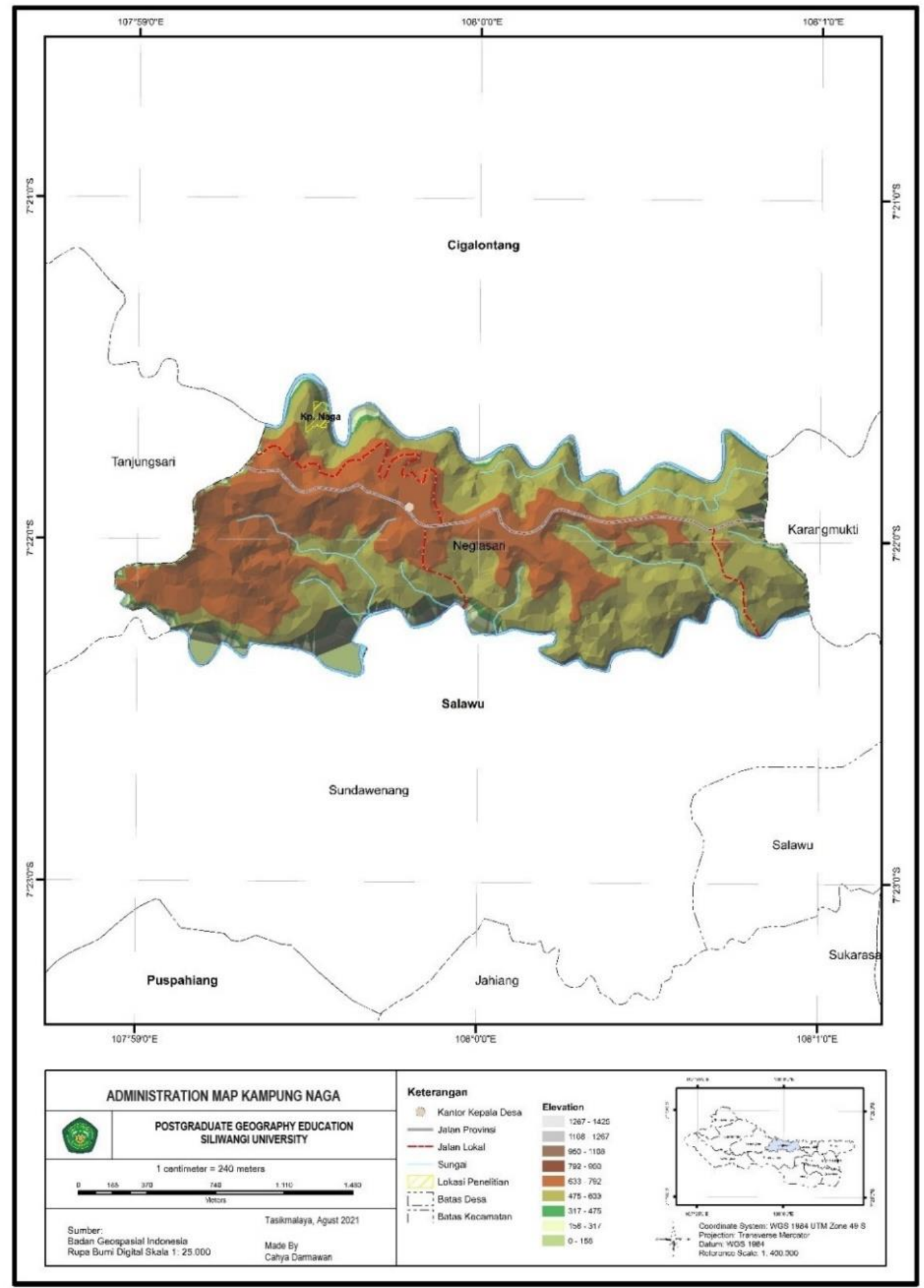

Figure 1. Location of Kampung Naga

The cultural potential in Kampung Naga is the main attraction for other people to come and visit Kampung Naga. This is the reason why Kampung Naga is included in the development area of the
Galunggung Geopark, because there are traditional villages that are well-known by decent people. Based on its form, this cultural potential is divided into two, namely tangible cultural potential and 
intangible cultural potential. The following is the cultural potential found in Kampung Naga based on tangible and intangible aspects.

\section{Tangible cultural potential in Kampung Naga}

Kampung Naga as a traditional village has a variety of cultural wealth that is tangible or in a real sense that can be seen and felt directly. Based on (Undang- Undang Republik Indonesia Nomor 11 Tahun 2010 tentang Cagar Budaya) tangible culture is grouped into five, namely :

\section{a. Cultural Heritage Things}

This cultural heritage object can be formed naturally or man-made which has a certain meaning. Cultural heritage objects found in Kampung Naga are heirlooms called Sanusantara heirlooms.

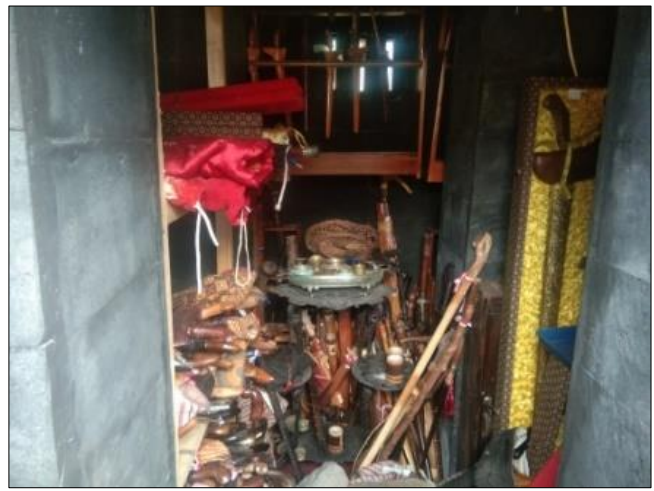

Figure 2. Sanusantara Heirlooms

This Sanusantara heirloom is a term for heirlooms collected by a humanist and stored in the cleaver monument of Kampung Naga. Even though they are not original heirlooms from Kampung Naga, these heirlooms are highly guarded and there is always a shower on the heirlooms in Rabiul Awal accompanied by the reading of the barjanji and terebang gembrung.

\section{b. Cultural Heritage Building}

Cultural heritage buildings are evidence of historical heritage in the form of buildings, which are the work of humans with the main characteristics of walls and roofs. The following are relics of cultural heritage buildings located in Kampung Naga:

\section{1) Kampung Naga Traditional House}

There are 112 traditional buildings in Kampung Naga and the number cannot be increased, consisting of 1 mosque, 1 meeting hall, 1 rice barn, 109 houses. Traditional houses or buildings in Kampung Naga characterize Sundanese buildings, namely houses on stilts. The layout of the houses in Kampung Naga is parallel to each other in the north and south and extends from east to west. The roof of the Kampung Naga house is made of fibers, the thicker the fibers, the stronger and longer lasting the roof of the house. Each house building in Kampung Naga has a different area but the house is usually divided into 4 parts, namely for the kitchen, living room, bedroom and goah.

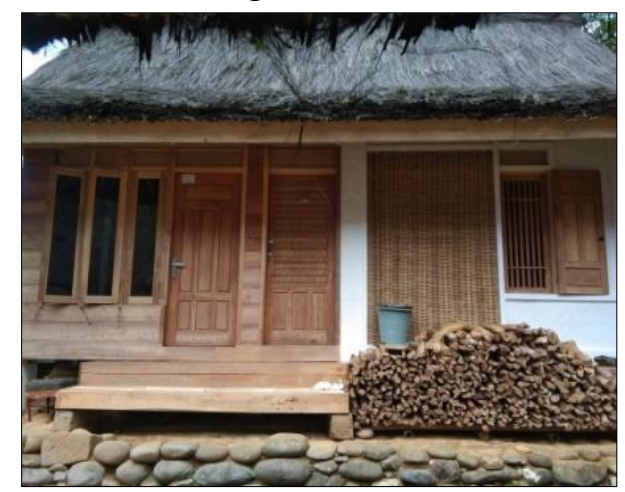

Figure 3. Kampung Naga

Traditional House

\section{2) Bumi Ageung}

Bumi ageung is a building that is very sacred and protected by the people of Kampung Naga, as a form of respect for their ancestors. The 
material used for this ageung earth is made entirely of woven bamboo called sasag. This building is very guarded so that not everyone can enter it, including the people of Kampung Naga. In addition, this ageung earth building should not be documented. The following is an image of the location of the earth ageung in Kampung Naga.

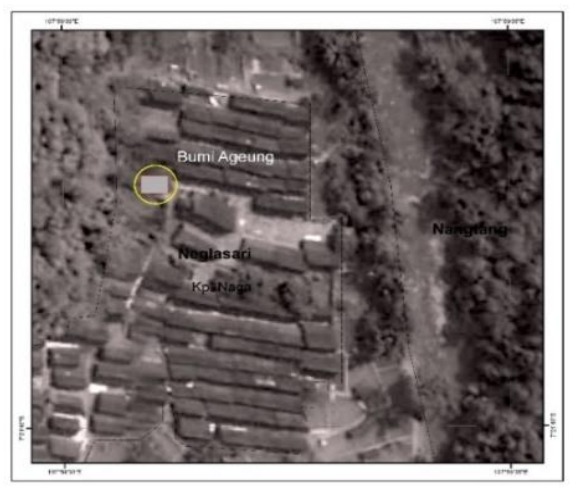

Figure 4. Bumi Ageung Satellite Image

\section{3) Bale Patemon}

Bale Patemon is a building that is used as a gathering place, a place for community deliberation or guests visiting Kampung Naga.

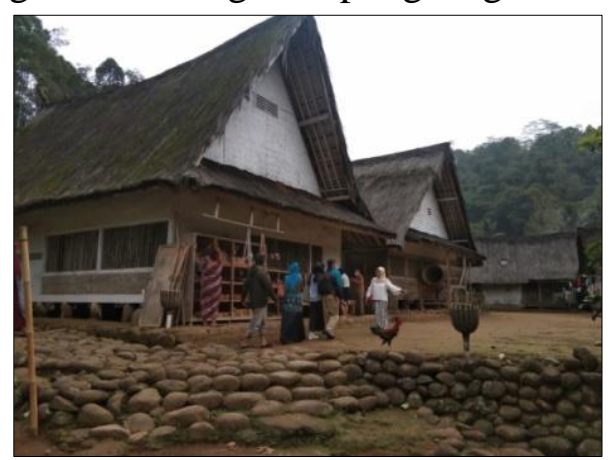

Figure 5. Bale Patemon

\section{4) Assalam Mosque}

The mosque in Kampung Naga is called the Assalam Mosque. Assalam mosque is always used as a place for the implementation of worship and other religious events. The building material is made of wood so it feels warm and cool inside.

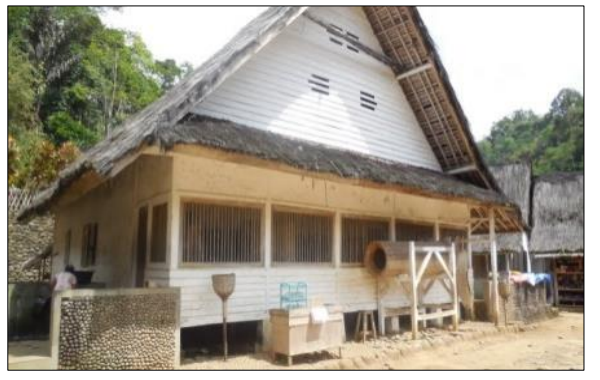

Figure 6. Assalam Mosque

\section{5) Kujang Heritage Monument}

The cleaver monument was made as a place to store Indonesian heirlooms collected by collectors and culturalists. The cleaver on the roof of the monument is an original heirloom that is the result of the fusion of 900 heirlooms. The location of the Kujang monument is located in the Kampung Naga parking lot.

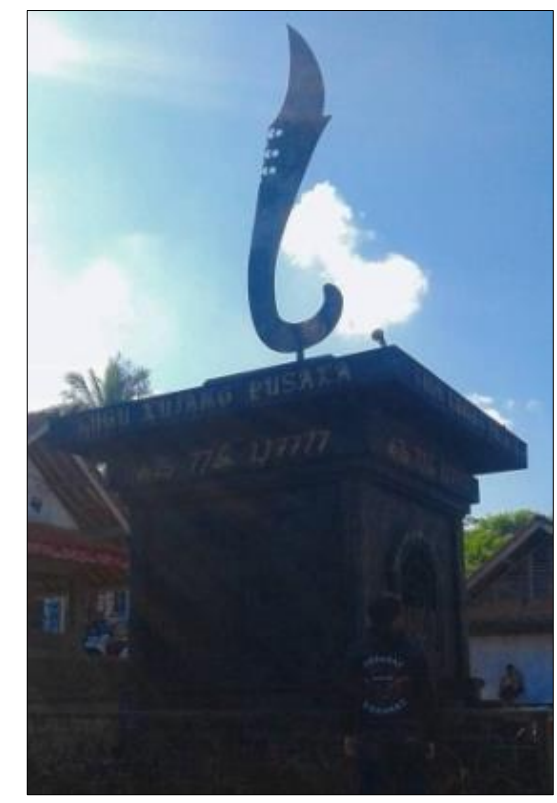

Figure 7. Kujang Monument

\section{6) Saung Lisung}

Saung lisung is a building made as a place to pound rice, the people of Kampung Naga still use the lisung to pound rice so that it becomes rice. Pounding rice is usually done by mothers. 


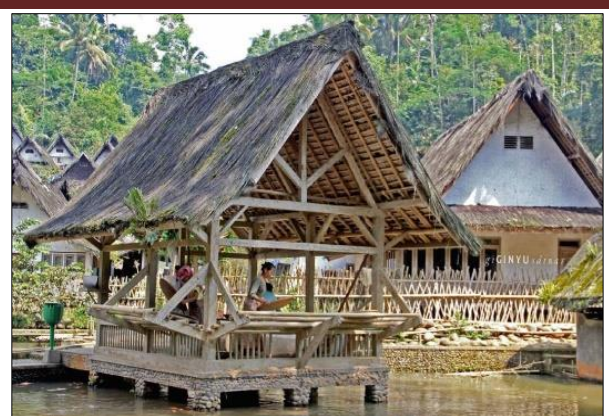

Figure 8. Saung Lisung

\section{7) Rice Barns}

After a fire occurred in 1956, a rice barn was rebuilt to store the community's agricultural products. This barn serves as a place to store rice given by the community when it is finished harvesting. Usually, the community gives rice in its class, for purposes that will be used together at every traditional event that is carried out.

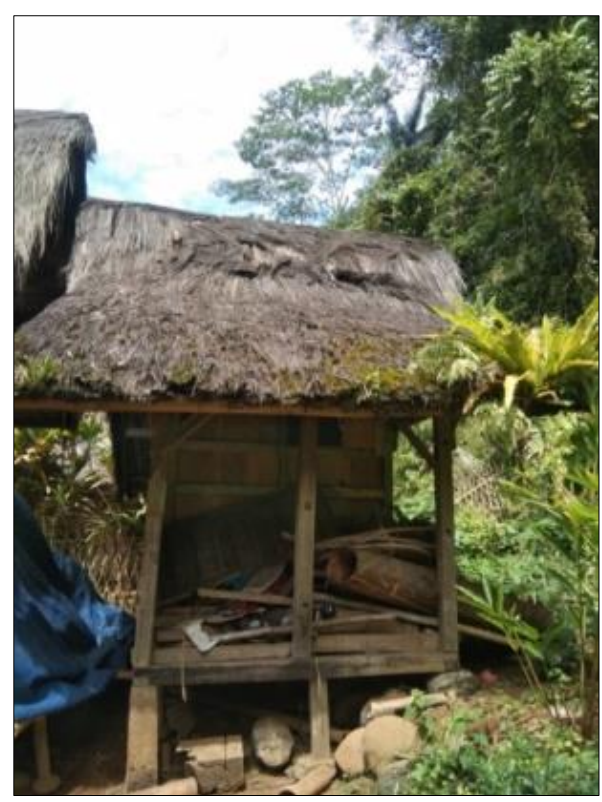

Figure 9. Rice Barns

\section{c. Cultural Heritage Structure}

The structure of the Cultural Conservation relates to the structure of the man-made or naturally formed structure made of natural objects that can be used to meet the needs of the activity space. Cultural Heritage Structures are usually integrated with nature, facilities and infrastructure to accommodate human needs. In Kampung Naga itself, there is no cultural heritage structure.

\section{d. Cultural Heritage Site}

Cultural Conservation Sites are closely related to the formation of historical relics of the past that are naturally formed and man-made products that have historical values or certain meanings. The following are historical sites in Kampung Naga:

\section{1) Pangsolatan Site}

Pangsolatan site is a place that used to be a place of prayer before the mosque. This pangsolatan site is a stretch of stone arranged in a rectangular shape (similar to a prayer). This pangsolatan site is located near the bank of the Ciwulan river for ablution. This pangsolatan site is very sacred and is kept sacred, and cannot be entered by anyone and for any purpose.

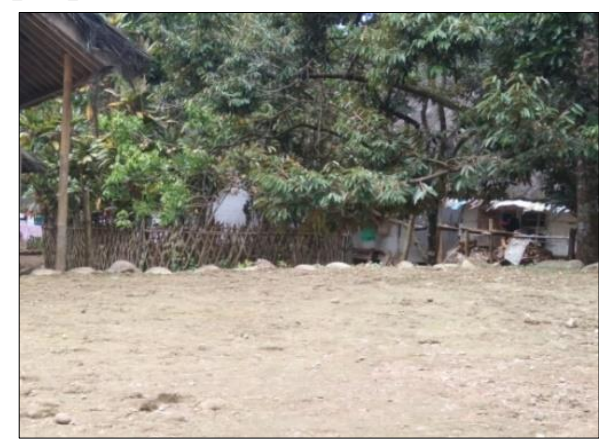

Figure 10. The Pangsolatan Site

\section{2) Granary Site}

In ancient times, our ancestors had set an example to maintain people's food security by establishing a rice barn. To be able to continue to respect the services of elders, a food and clothing patilasan was built, fenced by hanjuang trees. 


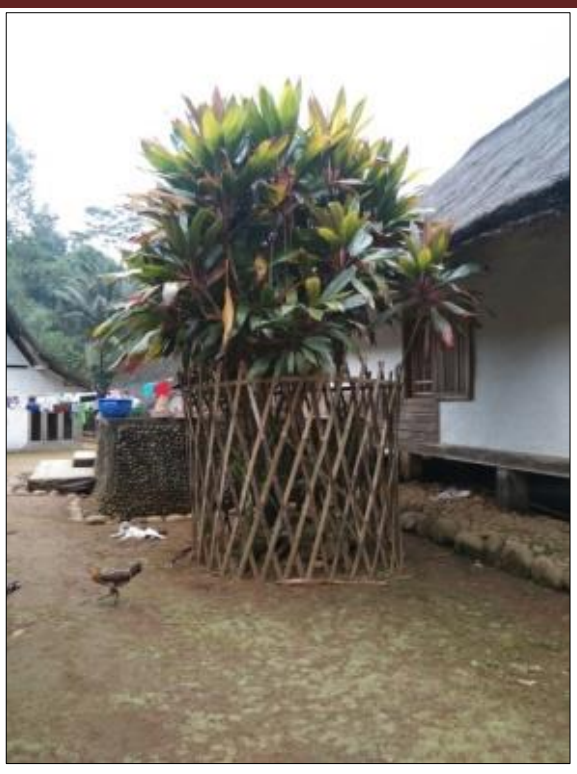

Figure 11. Granary Site

\section{e. Cultural heritage area.}

The cultural heritage area is related to a geographical space that has two cultural heritage sites that are located close together and have a distinctive feature or layout. Kampung Naga is a cultural heritage area which has various kinds of potential buildings, heritage sites which are located close to each other and are located in an area.

\section{Intangible Cultural Potential in Kampung Naga}

Based on the results of the UNESCO Convention (2003) intangible culture is a form of culture that is passed down from generation to generation, constantly recreated by a community group as a form of community response to its environment, interaction with nature, and history that provides identity in promoting respect for cultural diversity and human creativity. The intangible cultural potential consists of :

\section{a. Tradition and Oral Expression}

The people of Kampung Naga are Sundanese people who still adhere to their customs. The language used by the community to interact with other people is Sundanese.

\section{b. Performing Arts}

Is a form of culture that can be seen and felt and has the value of beauty contained therein. The following is an art that comes from Kampung Naga :

\section{1) Terebang gembrung}

Terebang gembrung is a musical instrument made of wood covered with sheepskin, the diameter of the Terebang gembrung is the same. The art of Terebang gembrung is only displayed when Mulud, Takbiran welcomes Eid alFitr or Eid al-Adha.

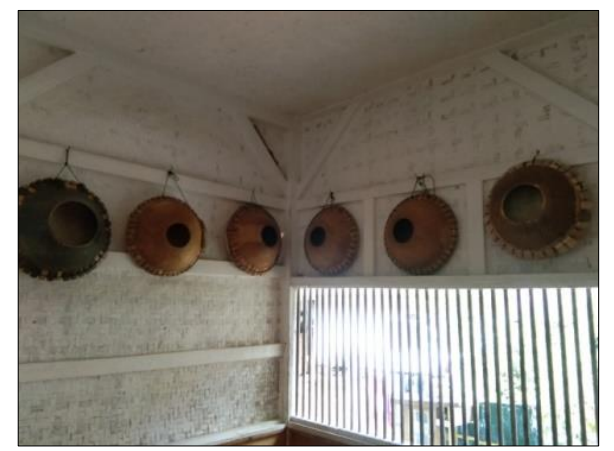

Figure 12. Terebang Gembrung

\section{2) Terebang Sajak}

Terebang sajak is a musical instrument that is almost the same as a tambourine, which is more entertainment in nature. The diameter of the rhyme fly varies from large to small, the number of terebang sajak is 4 pieces of tingting, kemprong, bangpak and brumbung with the addition of 1 musical instrument that looks like a lodong called gedebug. Terebang sajak poetry is usually performed at PHBN events, circumcisions, weddings. 


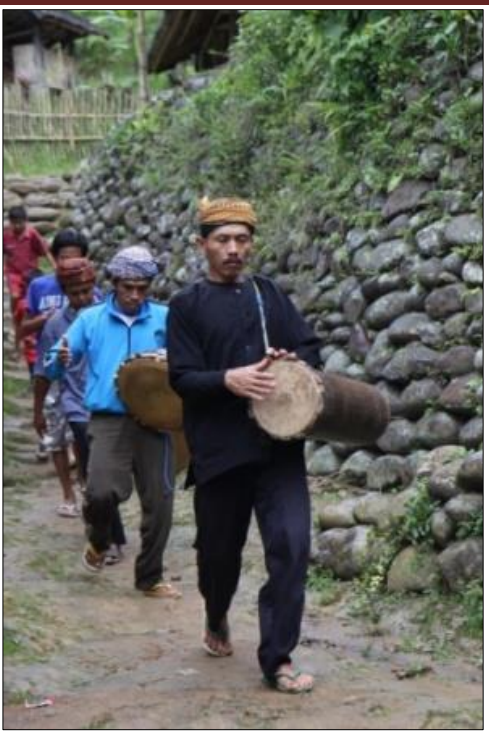

Figure 13. Terebang Sajak

\section{3) Angklung Buhun/Bangreng}

The art of angklung buhun is usually performed when there are traditional events such as when carrying out the work of intent. At the time of parading the circumcision bride is usually accompanied by musical instruments such as flying since and angklung buhun/bangreng which is played while circling the village.

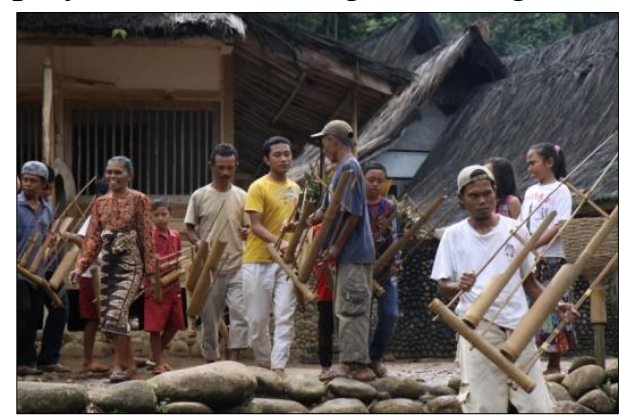

Figure 14. Angklung Buhun

\section{c. Community customs}

\section{1) Traditional Ceremony}

The people of Kampung Naga perform traditional ceremonies six times a year, namely the month of Muharram, Rabiul Awal, Jumadilakhir, Sya'ban, Syawal (Eid al-Fitr), Dzulhijah (Eid al-Adha). All traditional events are carried out on Islamic holidays and traditional events are carried out after the commemoration of Islamic holidays is complete. If the event is held on a taboo day, the implementation will be postponed to the next day. Traditional events are usually carried out by men because women prepare dishes to be eaten after the traditional ceremony is over.

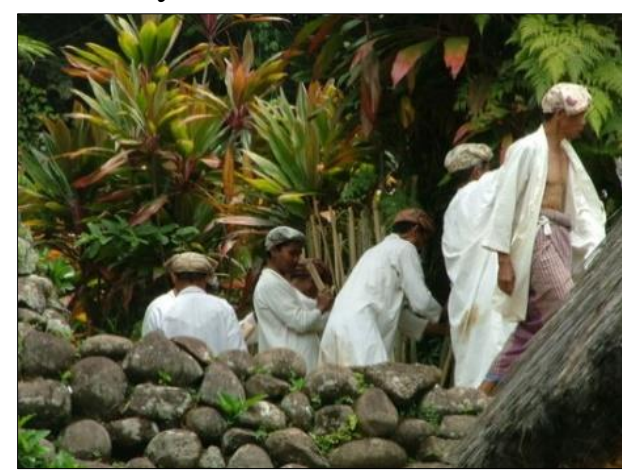

Figure 15. Traditional Ceremonial Traditions

\section{2) Marak}

Marak is a tradition carried out by the community to take fish in the Ciwulan river. The festivities are usually carried out in August before the 17th, usually lively activities are carried out by all Kampung Naga indigenous peoples and the surrounding community by inviting government agencies in Tasikmalaya Regency. The activity is lively led by traditional stakeholders and there is a ritual of splitting the coconut first to mark the start of the lively event, then damming the flow of the Ciwulan river and channeling it into the irrigation canal after the water recedes slightly then the community begins to take fish in the Ciwulan river. The endemic fish in the Ciwulan river are kekel, hurang and udikan fish. After finishing taking 
the fish, the people eat together on the riverbank. On August 17th, the people of Kampung Naga handed over the food they got and transported them in a stretcher including fish caught from live activities, this procession is called seba.

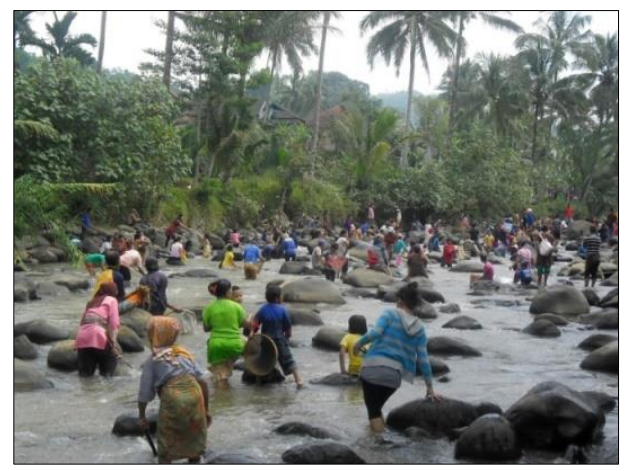

Figure 16. Marak

\section{3) Hajat Karya}

Hajat Karya is a festive event as a form of thanksgiving because a mass circumcision has been held. The implementation of Hajat Karya is not necessarily timed depending on the number of children to be circumcised. The event was held for one day and one night. To enliven the event, it is usually done by setting up a stage for performing arts (khaul) accompanied by a combination of Terebang Sajak and angklung buhun. The series of events carried out by the participants who will be circumcised usually the children will be purified first / bathed first in the Ciwulan river. After that, the sungkeman is to be prayed for, paraded around Kampung Naga for two rounds, the circumcision procession, then the sawer procession and ending with the khaul event / traditional community party at night.

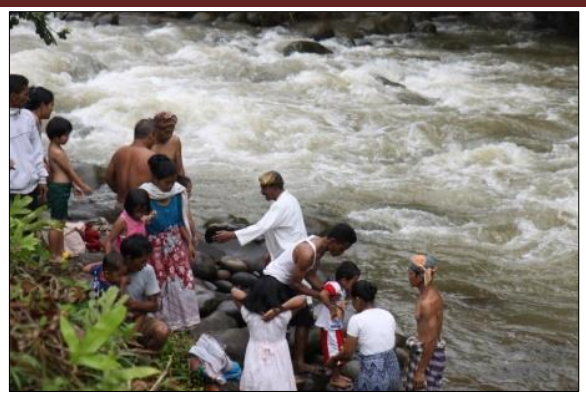

Figure 17. Hajat Karya

\section{d. Community Knowledge}

1) The farming system of Kampung Naga community

The livelihoods of the people of Kampung Naga are farmers, farming and gardening. The community still uses the traditional farming system, the rice seeds planted in Kampung Naga are local seeds that are six months old, so that in one year they are harvested twice. Before starting farming, the community always prepares offerings for traditional rituals.

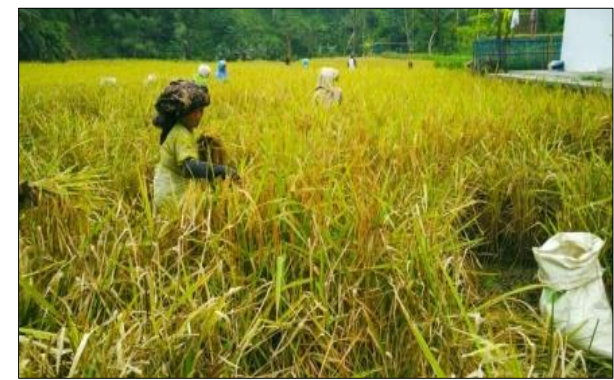

Figure 18. Kampung Naga farm

\section{2) Availability of homestay}

In providing comfort to visitors who come to Kampung Naga, usually guests who are far away can stay at the homes of Kampung Naga residents, of course with local community facilities. then besides that, homestays are available in the parking area with the quality of lodging in general. 


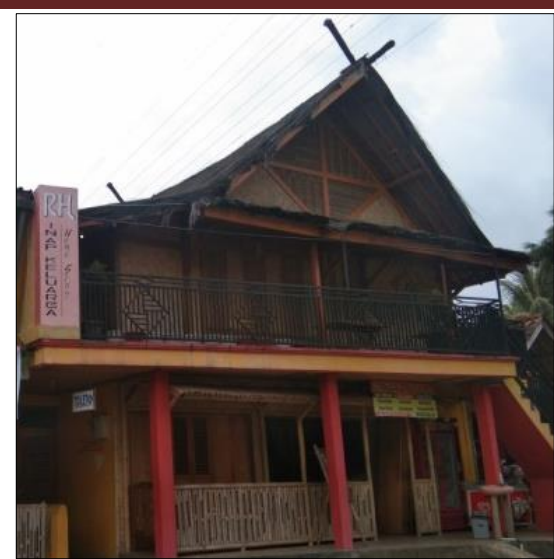

Figure 19. Homestay Kampung Naga

\section{3) Tour Guide Association}

The guides in Kampung Naga are indigenous people or those appointed by traditional institutions to be guides. The guide training was conducted by the DPD HPI West Java and information about the adat of Kampung Naga came from elders, kuncen or traditional institutions in Kampung Naga. The existence of HIPANA is very helpful in managing and developing tourism in Kampung Naga.

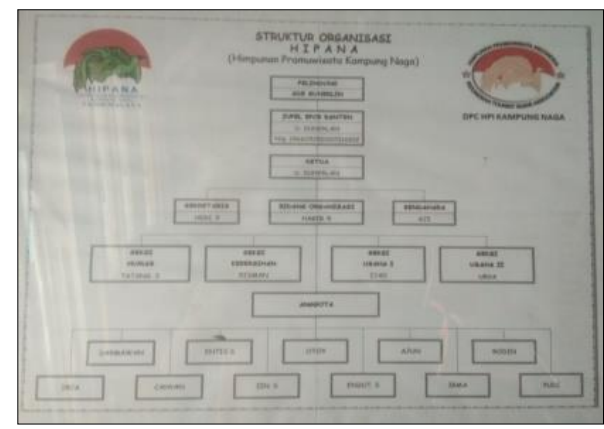

Figure 20. Kampung Naga Tour Guide Association

\section{4) Community UMKM}

Creative people will certainly be able to take advantage of and explore their potential. Most of the people of Kampung Naga develop UMKM in the handicraft sector of the local community such as making wickerwork, souvenirs and other crafts. They sell their handicrafts independently and are also sold through collectors.

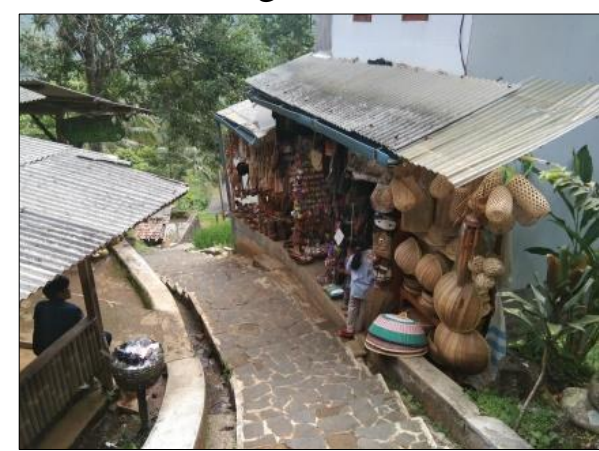

Figure 21. Community UMKM

\section{e. Traditional Craft Proficiency}

With the expertise possessed by the people of Kampung Naga, they are able to make a variety of traditional crafts from bamboo made of woven, lampshades, kitchen utensils, parcel holders and other crafts. These skills are acquired by the community from generation to generation and taught by their respective parents.

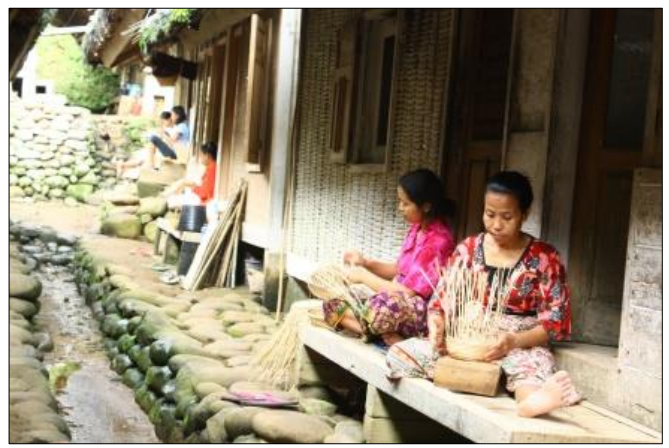

Figure 22. Craft Skills

\section{CONCLUSIONS}

The people of Kampung Naga are indigenous people who still adhere to their ancestral customs and traditions. There is a lot of cultural potential in Kampung Naga that provides extraordinary experience and knowledge. The people of Kampung Naga live in harmony with nature and have great respect for nature. The cultural potential that exists in the community at this time is a legacy from 
the ancestors of the dragon village which is still preserved, carried out in every activity.

The cultural potential in Kampung Naga can be seen from both tangible and intangible aspects. Cultural potential in the form of: (1) Cultural heritage things include Sanusantara heirlooms. Cultural heritage buildings include Kampung Naga Traditional House, Bumi Ageung, Bale Patemon, Assalam Mosque, Kujang Heritage Monument, Saung Lisung, and Lumbung. (3) There is no cultural heritage structure in the research location. (4) Cultural heritage sites include Pangsolatan site and Granary site. (5) The Cultural Conservation Area covers all the potentials contained in Kampung Naga. While the intangible culture potential consists of (1) Tradition and Oral Expression of the people of Kampung Naga still using Sundanese to communicate (2) Performing arts such as the art of musical instruments terebang gembrung, terebang sajak, angklung buhun (3) Customs consist of traditional ceremonies in commemoration of the big day Islam, the growing need for work (4) the knowledge system of the community consists of the agricultural system, homestay management, the Kampung Naga tour guide community, the UMKM Community (5) Traditional craft skills related to the community's expertise in making handicrafts from bamboo. All of these cultural potentials, both tangible and intangible, are unique characteristics possessed by the people of Kampung Naga, making this Kampung Naga a cultural heritage area. So that this Kampung Naga area is a superior area to promote the Geopark Galunggung in the aspect of cultural diversity.

\section{E. REFERENCES}

Bachri, S Bachtiar. 2010. "Meyakinkan Validitas Data Melalui Triangulasi Pada Penelitian Kualitatif." Jurnal Teknologi Pendidikan 10 (1).

Darmawan, Cahya, Siti Fadjarajani, and Iman Hilman. 2021. "CULTURAL DIVERSITY OF LOCAL COMMUNITIES TO CREATE GALUNGGUNG GEOPARK IN TASIKMALAYA REGENCY." Spatial: Wahana Komunikasi Dan Informasi Geografi 21 (1).

Fahrudi, Erista Zulki;, and Dheny Wiratmoko. 2018. "Masyarakat Geopark Gunung Sewu Pacitan Dalam Perspektif Ekonomi, Tradisi Dan Budaya." JURNAL AGASTYA 08 (01).

Faisal, Mohammad, Moh Gamal Rindarjono, and Chatarina Muryani. 2016. "ANALISIS LUBUK LARANGAN SEBAGAI WISATA EKOLOGI BERBASISKAN KEARIFAN LOKAL DESA LUBUK BERINGIN, KECAMATAN BATHIN III ULU, BUNGO, JAMBI (Sebagai Pendukung Substansi Materi Pengelolaan Sumber Daya Alam Pada Bidang Studi Geografi Di Kelas XI SMA)." Jurnal GeoEco 2 (2): 103-13.

Goeldner, C, Harles R., and J. R. Brent Ritchie. 2012. Tourism: Principles, Practices, Philosophies. New Jersey: John Wiley \& Sons, Inc.

Gubernur Jawa Barat. 2018. "PERGUB Nomor 72 Tahun 2018 Tentang Pengembangan Kawasan Geopark Di Daerah Provinsi Jawa Barat."

Illiyani, Maulida. 2018. "BERFIKIR INTELEKTUAL, BERWAWASAN $\begin{array}{lcr}\text { GLOBAL, DAN } & \text { TETAP } \\ \text { MELANGKAH } & \text { LOKAL": } \\ \text { PROSPEK } & \text { KAMPUNG } & \text { NAGA } \\ \text { MENJADI } & \text { DESA } & \text { ADAT." }\end{array}$ 
Masyarakat \& Budaya 20 (1).

Kamardi, Agus Dono. 2007. "Budaya Lokal Sebagai Warisan Budaya Dan Upaya Pelestariannya.” Jawa Tengah.

Kusumahbrata, $\quad$ Yunus. 2020. "Pengembangan Aspiring Geopark Galunggung Tasikmalaya." Jakarta.

Nurhanifa, Eka Rahma;, Neneng; Konety, and Raden Muhammad Teguh Nurhasan Affandi. 2020. "Diplomasi Publik Baru Indonesia Terhadap UNESCO Dalam Menjadikan Kawasan Geopark RinjaniLombok Sebagai Geopark Global UNESCO." Padjadjaran Journal of International Relations (PADJIR) 1 (3). https://doi.org/10.24198/padjir.v1i3. 26195.

Pemerintah Desa Neglasari. 2020. "Data Sensus Penduduk Desa Neglasari Tahun 2020.” Tasikamalya.

Stoffelen, Arie, Pete Grootea, Erik Meijlesa, and Gerd Weitkampa. 2019. . ". Geoparks and Territorial Identity: A Study of the Spatial Affinity Ofinhabitants with UNESCO
Geopark De Hondsrug, The Netherlands." Elsevier Applied Geography 106. https://doi.org/https://doi.org/10.101 6/j.apgeog.2019.03.004.

Sukmadinata, Nana. 2015. Metode Penelitian Pendidikan. Bandung: Rosda Karya.

Taylor, K. 2013. "Cultural Mapping: Intangible Values and Engaging with Communities with Some Reference to Asia." The Historic Environment 4 (1): 50-61.

Timang, Vica Vanessa Sesaryo, Antariksa, and Ismu Rini Dwi Ari. 2016. "Pelestarian Dukun Buntula'bi Balusu Sebagai Warisan Budaya Di Kabupaten Toraja Utara." Jurnal Penataan Ruang 11 (1).

Undang- Undang Republik Indonesia Nomor 11 Tahun 2010 tentang Cagar Budaya. 2010. "Undang- Undang Republik Indonesia." Jakarta.

UNESCO. 2003. "The Convention for the Safeguarding of the Intangible Cultural Heritage." Paris. 